\title{
Psychiatric disorders and psychiatric consultation in a general hospital: a case- control study
}

\section{Transtornos psiquiátricos e solicitações de interconsulta psiquiátrica em hospital geral: um estudo de caso controle}

\author{
Sumaia Inaty Smaira ${ }^{\mathrm{a}}$, Florence Kerr-Corrêa ${ }^{\mathrm{b}}$ and José Onildo B Contel ${ }^{\mathrm{c}}$ \\ ${ }^{a}$ Department of Neurology and Psychiatry of the Medical School of the State University of São Paulo (UNESP). Botucatu, SP, Brazil. ${ }^{b}$ Department of \\ Neurology and Psychiatry of the Medical School of Botucatu of the UNESP. Botucatu, SP, Brazil. 'Medical School of Ribeirão Preto, University of São Paulo \\ (USP). São Paulo, SP, Brazil
}

Abstract Introduction: Psychiatric consultation (PC) has been considered an efficient tool to develop research, to track and to give assistance benefiting patients, health professionals and the institution. However, it has not been much used in Brazil. Although 30 to 50\% of general hospital (GH) inpatients may present a psychiatric disorder, only 1 to $12 \%$ of them are referred to assessment. The aims of this study were: to assess mental disorders in a $\mathrm{GH}$; to identify which of these patients are sent to psychiatric care; to verify alleged reasons for referral to psychiatric consultation, and to examine the relationship between PC and psychiatric learning (during medical school and residence).

Methods: A case-control patient study was conducted (47 cases and 94 controls) to analyze in detail the following variables: socio-demographic; clinical; degree of information (about the disease and diagnostic/therapeutic procedures), and relationship between patient and health team. Psychiatric diagnoses were made according to the ICD-10 criteria. The Self Report Questionnaire (SRQ), the CAGE and Brief Psychiatric Rating Scale (BPRS) were used as well as a specifically designed questionnaire to collect clinical and demographic data.

Results: Behavioral alterations, either of elation or of depression, were the main for requesting a PC ; 95.8\% of the cases and $27.7 \%$ of the controls had a mental disorder. Organic mental disorders and alcohol-related disorders were the most frequent diagnoses in group I (cases), while anxiety, depressive and alcohol-related disorders were predominant in group II (controls). Control group patients were better informed and more able to establish an appropriate relationship with the health team than case patients. The logistic regression showed CAGEpositive patients having 12.85 times greater risk of being referred to $\mathrm{PC}$, followed by unemployed patients ( 2.44 times more $\mathrm{PC}$ referrals).

Discussion: The SRQ and CAGE were quite useful in the screening of possible patients and might be important for medical students to learn and use as generalists. Further research is needed to verify if and how the newlyestablished service will improve the diagnostic and treatment skills of our students.

Keywords Psychiatric disorders. General hospital. Psychiatric consultation. Case- control study.

Resumo Introdução: A interconsulta psiquiátrica (ICP) pode ser considerada um instrumento de pesquisa, ensino e assistência, que beneficia paciente, equipe de saúde e instituição. A sua utilização no Brasil é ainda pequena. Sabe-se que $30 \%$ a $50 \%$ dos pacientes internados em hospital geral (HG) podem apresentar uma patologia psiquiátrica, mas que apenas $1 \%$ a $12 \%$ destes são encaminhados para avaliação. Pretendeu-se com este trabalho caracterizar os transtornos psiquiátricos no HG; identificar as diferenças entre pacientes encaminhados e um grupo controle.

Método: Realizou-se um estudo caso-controle de 141 pacientes (47 casos e 94 controles), analisando variáveis sócio-demográficas, clínicas, informação quanto à doença, procedimentos diagnósticos e terapêuticos; e relação pacientes- equipe de saúde. Utilizou-se o Self Report Questionnaire (SRQ), o CAGE e o Brief Psychiatric Rating Scale (BPRS), além de um questionário elaborado para o estudo.

Resultados: Observou-se que alterações de comportamento com manifestações de exaltação e depressivas motivaram os pedidos de ICP; $95,8 \%$ dos casos e $27,7 \%$ dos controles receberam um diagnóstico psiquiátrico; 
transtornos orgânicos e alcoolismo prevaleceram no grupo I (casos), e os transtornos de ansiedade e transtornos depressivos no grupo II (controles). Pacientes do grupo controle estavam mais bem informados e estabeleceram relacionamentos mais adequados com a equipe de saúde que os casos. A regressão logística mostrou que pacientes com CAGE positivo têm 12,85 vezes mais chances de serem encaminhados para ICP; os sem ocupação 2,44 vezes; ou seja, alcoolismo e alterações cognitivas foram os principais responsáveis pelo encaminhamento à ICP.

Discussão: O uso de instrumentos de triagem, como o SRQ e o CAGE, pode ser útil na formação do clínico geral. Pesquisas adicionais deverão ser feitas para avaliar de que maneira o serviço de ICP implantado melhorou as habilidades de diagnóstico e tratamento de transtornos psiquiátricos neste hospital geral universitário.

Descritores Transtorno psiquiátrico. Hospital geral. Consultoria. Caso controle.

\section{Introduction}

Studies about prevalence of psychiatric disorders in inpatients of general hospitals show that there is an association between physical and psychiatric diseases ${ }^{1}$. Estimates of psychiatric morbidity in these patients range from $20 \%$ to $60 \%$ and that of referrals for assessment by specialists vary only from 1 to $13 \%$ of the ${\text { cases. }{ }^{1,2} \text { For Seltzer }}^{3}$ (1989), the low level of referral of these cases is due to their not being detected by the team of physicians and nurses, what in turn would cause not only the persistence of the problem, but also the increase in the mortality level. He also highlights the scarce attention that has been given to non-referred cases. ${ }^{1}$ In the same study the author reported that, although $31 \%$ of admitted patients had any of their affective symptoms recognized by the team, to few of them Psychiatric Consultation (PC) was requested. Besides, Seward et $\mathrm{al}^{4}$ (1991) considered that the organization of the consultation service and its efficiency are factors that somehow interfere with the rates of referral to psychiatric assessment.

The reasons that induce clinicians, surgeons and other team members to ask for the psychiatrist's help were listed by several authors ${ }^{5-10}$ and are: doubts concerning the patients' diagnosis or difficulty to deal with the diagnosed disturbance; to collaborate with the differential diagnosis between organic and psychical pathologies; persistence of the patient's complaints, despite the adopted conduct; patients' behaviors disturbing the ward's functioning; the team been sensibilized by the patient's attitudes and difficulty to deal with the provoked feelings or reactions; suicidal attempt and/or risk and patients with psychiatric disturbances or antecedents and disadjustments in the patient- physician relationship, among others

In Brazil, the number of PC services is still unknown and most of them are probably situated in university hospitals. ${ }^{7}$ Since its foundation in 1974, the psychiatric service of the Clinical Hospital $(\mathrm{CH})$ of the Medical School of the city of Botucatu has been seeing psychiatric occurrences by means of consultations, and the studies performed in the CH-UNESP have shown referral rates below $1 \%$ in the last years. ${ }^{6,8,9}$

Considering the above-described factors, the need of a constant assessment of the quality of the rendered services and the scarcity of national studies investigating the factors possibly related to low referral, this study aimed: to assess the clinical, psychical and socioeconomic characteristics of patients to whom PC was requested in the CH-UNESP and to compare them to a control-group.

\section{Methods}

We have chosen for this study the case-control method.

\section{Subjects}

One hundred and forty-one inpatients of the CH-UNESP, subdivided in two groups were interviewed, after the research's goals had been explained and they had given the informed consent (and/or from a family member) to participate in the study:

- Group I (cases) - composed by patients for whom there have been PC requisitions, between May and October 1995, except for those hospitalized in the Intensive Care Unit, Emergency Care and Pediatric Unit. The final sample of 47 patients originated from the following situation: out of 74 consultations requested in this period, 7 were for patients in a coma or being ventilated; 6 for patients at their discharge; 9 patients who were assessed by the PC service were discharged before the research interview and 6 patients in the same conditions had deceased.

- Group II (controls) - composed by 94 randomically allotted patients among those to whom a PC had not been requested and who met the following matching criteria with group I: requesting clinic, gender and age range. Exclusion criteria were: medical records had a PC requisition and absence of clinical conditions for to participate in the interview.

\section{Instruments used}

Questionnaire to obtain socioeconomic and clinical data QSD/C,* for this study, we developed a questionnaire with 24 items, subdivided in three categories: 1) sociodemographic data; 2) clinical data, ward in which the patient was hospitalized, clinical diagnosis; 3) data related to the consultation, when it had been requested and performed.

SRQ (Self Report Questionnaire), ${ }^{11}$ which is a questionnaire for the identification of psychiatric disorders in primary care settings, validated in Brazil by Mari \& Willians. ${ }^{12}$ It is composed by 24 questions, subdivided in two sections: the first one with 20 questions formulated to detect 'neurotic' disor- 
ders and the second with four questions, in order to detect psychotic disorders. Due to the epidemiological importance of alcoholism, questions of the CAGE were included. ${ }^{13,14}$

BPRS (Brief Psychiatric Rating Scale), ${ }^{15}$ validated in Brazil by Zuardi et al, ${ }^{16}$ utilized to assess the psychopathology of cases and controls. Despite being an instrument developed for pharmacological researches, it has shown to be useful to describe the psychopathology, due to the similarity of its items and concepts with the usual form in which clinicians inform these alterations, for the easiness of its application, besides covering a wide range of psychiatric manifestations. ${ }^{16}$ The BPRS is a semistructured instrument, composed by 18 items, based on the patient's verbal information and on the observed behavior during the interview.

\section{Researching procedures}

The interview to apply the proposed instruments in group I patients always occurred after the routine of the consultation service had been performed, as to not cause great interference in its results. Interviewers (three psychiatrists) were previously trained to use the instruments by means of discussions and of ten joint interviews. Psychiatric diagnoses of groups I and II were respectively reassessed and accomplished by the researchers using the ICD-10 criteria. $^{17}$

\section{Statistical analysis}

The statistical analysis had two stages: 1) description of the sample through the distribution of frequencies and the association between intra-group and inter-groups variables and 2) multivariate analysis (analysis of dependence) - as it allows to explain, through a series of qualitative and quantitative analyses, the probability of a patient hospitalized in the wards of the CH-UNESP to be referred to PC. The relationship between the variables of interest was determined by the chi-square test. Information was analyzed by means of the statistical programs Epi-info 6.0 and SPSS version 7.0. The adopted significance level was $5 \%$.

The dependent variable (being referred to PC), explained by the independent variables, is a binary one, having values of one (1) if the patient was referred to PC (cases) and zero (0) if the patient belonged to the control group. Independent variables were included in the model in two stages: First - all variables; Second - marital status, origin, occupation, clinical diagnosis, awareness of the pathology/prognosis/treatment, relationship with the medical team; reason for a $\mathrm{PC}$ requisition; psychiatric diagnostic hypothesis $(\mathrm{PDH})$ of the requesting physician; variables corresponding to data from the $\mathrm{PC}$

Tabela 1 - Motivos de solicitação de Interconsultas Psiquiátricas dos 47 pacientes atendidos no período de maio a outubro de 1995 , Serviço de ICP do HC-UNESP, Botucatu.

\begin{tabular}{lrc}
\hline & $\mathrm{N}$ & $\%$ \\
\hline Alteração de comportamento & 17 & 36,2 \\
Dúvida diagnóstica e/ou terapêutica & 11 & 23,4 \\
Antecedentes psiquiátricos & 8 & 17,0 \\
Paciente pouco colaborativo & 8 & 17,0 \\
Tentativa de suicídio & 3 & 6,4 \\
\hline
\end{tabular}

when requested and performed, and used instruments and scales (variables with statistically significant difference between the groups were included in the second stage).

\section{Results}

\section{Description of the sample}

Due to the matching of patients, there was an equivalence between groups with regards to gender $(51.1 \%$ males and $48.9 \%$ females) and age range (between 20 and 39 years, 38.3\% and above 60 years, 34\%). Of note, there was a clearly higher proportion of married subjects in the control group, $\left(x^{2}=12.09\right.$; $\mathrm{p}=0.0005$ ). Regarding profession, most patients had manual jobs with few or none specialization $(36.2 \%)$, were housewives $(21.3 \%)$ or retired $(27.7 \%)$. In the control group there were no differences in this distribution.

\section{Referral factors and associations}

$\mathrm{PC}$ was requested mainly in the first hospitalization week $(72.3 \%)$, for patients with the following diagnostic groups: neoplasias $(19.1 \%)$, traumas $(17.0 \%)$, systemic diseases (14.9\%), infectious diseases (12.8\%), gastrointestinal diseases and skin $\&$ appendages diseases (10.6\% each). Although there had been no matching for diagnosis, the difference between cases and controls in the diagnostic groups was not significant.

Table 1 shows data related to the reasons for requesting PC, written in the forms. In $36.2 \%$ of the cases there was a report of behavioral alteration with depressive mood as well as elation, with restlessness and/or agitation, being implied that this would be the reason for a PC requisition, followed by a demand to help in the orientation regarding the conduct for the case. In $23.4 \%$ of the cases the reported reason was a diagnostic or therapeutical doubt. The remaining requisitions referred to the presence of psychiatric antecedents $(17.0 \%)$ or to any difficulty in the relationship with the patient $(17.0 \%)$.

We verified that the solicitant had elaborated psychiatric diagnostic hypotheses in $21.2 \%$ of the cases, as follows: $14.9 \%$ for alcoholism, $4.2 \%$ for suicide attempt and $2.1 \%$ for depression. A symptomatological description without diagnostic formulation occurred in $46.8 \%$ of the requisitions. Confusional symptoms were described in $23.4 \%$ of the cases, depressive symptoms in $12.8 \%$ of them and anxious symptoms appeared in $10.6 \%$. Thirteen requisitions $(27.7 \%$ ) had no diagnostic hypothesis and/ or descripion of the case, only socio-demographic data and the standard requisition: 'assessment and conduct are requested'.

Consultant psychiatrists in their assessment made the following diagnoses, in frequency order: 1) organic mental disorders $(29.8 \%) ; 2)$ disorder secondary to alcohol abuse $(21.3 \%)$; 3 ) depressive disorders $(21.3 \%)$; 4 ) anxiety disorder $(12.8 \%)$ and conversive disorder $(10.6 \%)$. In $4.2 \%$ of the cases there was no diagnosed psychiatric disease.

Table 2 shows data related to the psychiatric diagnoses for groups I and II. Twenty-seven point seventy percent of patients of the control group had received some diagnosis during the evaluation.

Table 3 shows descriptive data of the symptomatology assessed by the BPRS. Symptoms were considered as present 
when the punctuation of each item was equal to or higher than two. Of note, more than $60 \%$ of group I patients had psychical anxiety, tension and depressed mood, whereas in group II the psychical anxiety was present in $38.3 \%$ of patients as well as depressed mood in $28.7 \%$ and tension in $24.5 \%$ of them.

\section{Results of the multivariate statistical analysis}

First Phase - the model contained all the variables of the protocol, except those that were matched. Table 4 was obtained after the CAGE- positive stepwise procedure:

- That is, if there were two or more affirmative questions, the chance of the patient being referred to $\mathrm{PC}$ was higher than in the negative case.

- Patients with psychopathological alterations compatible with the diagnosis of organic mental disorder and alcoholism (according to ICD-10 criteria) had higher chances of being referred to $\mathrm{PC}$ than those with depressive-anxious pictures.

- Unoccupied subjects, retirees and housewives had a higher chance, in a decreasing order, of being referred to $\mathrm{PC}$, than subjects with any formal job.

Second Phase-Using only the variables chosen and described in subjects and methods (table 5), we obtained the explanatory model II, described below:

- The likelihood of being referred to PC was higher when the SRQ was positive, that is, score $>6$.
- The non-identification of the physician in charge, as well as the lack of psychic conditions for interaction, increased the chances of patients being referred to PC.

\section{Discussion}

\section{Sociodemographic data}

Regarding the socio-demographic characteristics of the studied population, there were no differences concerning gender, both being equally represented, what agrees with some data from the literature. ${ }^{5,6,18}$ Some authors, ${ }^{19,20}$ however, verified that women are referred to consultation twice as much as men. Shevitz ${ }^{19}$ justifies this fact by women having a higher trend for depression than men, being this one of the most frequent diagnoses found in the literature about consultation.

Regarding age, $47.6 \%$ of the patients were older than 50 years and $34.8 \%$ aged 60 or more. These data are similar to those found in the literature. ${ }^{4,18,19}$ According to Lipowski, ${ }^{1}$ nearly $30 \%$ of patients referred to psychiatric consultation aged more than 60 , reminding the fact that $30 \%$ of medico-surgical hospitalizations occur in the same group.

An interesting finding was obtained regarding the patients' marital status: there was a significantly higher number of single $(44.7 \%)$ or widowers and separated) $(11 \%)$ patients among cases than among controls. We may suppose that people without close

Tabela 2 - Diagnósticos psiquiátricos de pacientes e controles e a chance de ser encaminhado para ICP. Serviço de ICP HC-UNESP, Botucatu, $1995 / 1996$.

\begin{tabular}{|c|c|c|c|c|c|}
\hline & \multicolumn{2}{|c|}{$\begin{array}{l}\text { Casos } \\
(n=47)\end{array}$} & \multicolumn{2}{|c|}{$\begin{array}{c}\text { Controles } \\
(n=94)\end{array}$} & \multirow[t]{2}{*}{$\begin{array}{l}\text { Chance } \\
\text { de ICP }\end{array}$} \\
\hline & $\mathrm{N}$ & $\%$ & $\mathrm{~N}$ & $\%$ & \\
\hline Transtorno mental orgânico & 14 & 29,8 & 3 & 3,2 & 4,7 \\
\hline Alcoolismo* & 10 & 21,3 & 7 & 7,4 & 1,4 \\
\hline Transtorno depressivo & 10 & 21,3 & 9 & 9,7 & 1,1 \\
\hline Transtorno de ansiedade & 6 & 12,8 & 7 & 7,4 & 0,8 \\
\hline Transtorno conversivo & 5 & 10,6 & - & - & $\infty$ \\
\hline Sem diagnóstico & 2 & 4,2 & 68 & 72,3 & 0,03 \\
\hline
\end{tabular}

Tabela 3 - Proporção de pacientes (casos e controles) com alterações psicopatológicas segundo a BPRS* e a média da gravidade de cada sintoma. Serviço de ICP HC-UNESP, Botucatu.

\begin{tabular}{|c|c|c|c|c|c|c|}
\hline Sintomas & \multicolumn{2}{|r|}{$\begin{array}{l}\text { Casos } \\
N=47\end{array}$} & sd & $\begin{array}{c}\text { Pacientes } \\
\%\end{array}$ & $\begin{array}{l}\text { Controles } \\
\text { N=94 } \\
\text { Média }\end{array}$ & sd \\
\hline Preocupação somática & 31,9 & 0,91 & 0,88 & 11,7 & 0,33 & 0,71 \\
\hline Ansiedade psíquica & 66,0 & 1,47 & 0,88 & 38,3 & 0,84 & 0,99 \\
\hline Distanciamento emocional & 14,9 & 0,30 & 0,72 & 2,1 & 0,04 & 0,29 \\
\hline Desorganização conceitual & 34,0 & 0,75 & 0,99 & 3,2 & 0,07 & 0,37 \\
\hline Auto depreciação /Sentimento de culpa & 17,0 & 0,40 & 0,82 & 5,3 & 0,10 & 0,45 \\
\hline Tensão & 61,7 & 1,32 & 1,00 & 24,5 & 0,55 & 0,93 \\
\hline Distúrbios motores & 14,9 & 0,21 & 0,50 & 2,1 & 0,04 & 0,29 \\
\hline Auto estima exagerada & 2,1 & 0,02 & 0,15 & 3,2 & 0,06 & 0,35 \\
\hline Humor depressivo & 53,2 & 1,28 & 1,28 & 28,7 & 0,66 & 1,01 \\
\hline Hostilidade & 23,4 & 0,51 & 0,78 & - & - & - \\
\hline Desconfiança & 29,8 & 0,70 & 0,95 & 1,1 & 0,02 & 0,21 \\
\hline Alucinações & 14,9 & 0,38 & 0,85 & 2,1 & 0,05 & 0,31 \\
\hline Retardo psicomotor & 25,5 & 0,57 & 0,88 & 3,2 & 0,06 & 0,35 \\
\hline Falta de cooperação & 17,0 & 0,43 & 0,90 & 1,1 & 0,02 & 0,21 \\
\hline Conteúdo do pensamento & 23,4 & 0,53 & 0,95 & 2,1 & 0,04 & 0,29 \\
\hline Embotamento afetivo & 8,5 & 0,21 & 0,66 & - & - & - \\
\hline Agitação psicomotora & 27,7 & 0,64 & 1,09 & - & - & - \\
\hline Desorientação / Confusão & 46,8 & 1,15 & 1,23 & 1,1 & 0,04 & 0,32 \\
\hline
\end{tabular}

${ }^{*} B P R S$ - Brief Psychiatric Rating Scale 
Tabela 4 - Resultado da regressão logística usando todas as variáveis explicativas.

\begin{tabular}{lccrr}
\hline Variável & $\begin{array}{c}\text { Parâmetro } \\
\text { estimado }\end{array}$ & $\begin{array}{c}\text { Erro } \\
\text { padrão }\end{array}$ & $\begin{array}{c}\chi^{2} \\
\text { Chazão de }\end{array}$ \\
\hline CAGE & 2,55 & 1,18 & 4,68 & 0,0304 \\
Diagnóstico Psiquiátrico & 1,01 & 0,30 & 13,52 & 0,0002 \\
Ocupação & 0,89 & 0,31 & 8,057 & 0,0045 \\
\hline
\end{tabular}

Tabela 5 - Resultado da regressão logística com as variáveis explicativas escolhidas.

\begin{tabular}{lcccc}
\hline Variável & $\begin{array}{c}\text { Parâmetro } \\
\text { estimado }\end{array}$ & $\begin{array}{c}\text { Erro } \\
\text { padrão }\end{array}$ & $\begin{array}{c}\chi^{2} \\
\text { Chances }\end{array}$ & $\begin{array}{l}p \\
\text { SRQ }\end{array}$ \\
\hline Identificar o médico & 0,39 & 0,85 & 3,94 & 0,0471 \\
\hline
\end{tabular}

affective links tend to show more remarkable emotional reactions, mainly during a disease or a hospitalization. We did not consider here the issue of the validity of these links and/or bonds. In the literature we found similar data: Smith et $\mathrm{al}^{21}$ found that $24 \%$ of their sample lived alone at the evaluation time; Creed et $\mathrm{al}^{22}$ found $29 \%$ of single and $15 \%$ of widower or separated subjects. Another likely hypothesis for this fact is that the presence of a psychiatric or even physical disease with the usual severity and chronicity features, leading to limitations, would decrease the possibilities of a subject to marry (having/keeping relationships) or would act as a facilitator of separations.

The observed low schooling and scarce professional specialization, regardless gender, may be explained by the fact that it was a public university school. Comparing both groups we observed that only a small part of cases $(4.3 \%)$ had any specialization, whereas in controls this rate reached to $23,4 \%$ of the reports. This finding might be related to the fact that many times the psychiatric pathology can prevent the subject to achieve higher technical skills or may lead him/her to lose these abilities.

\section{Requesting clinics and referral rate}

In the studied period 4,527 patients were hospitalized in the wards that were included in the study, out of which $74(1.6 \%)$ received a $\mathrm{PC}$ requisition, rate that was near to the lower limit presented in the literature, which ranged from 1 to $12 \%{ }^{2,4,23}$

Regarding the requesting specialty, the absolute number of requisitions from surgical areas was slightly higher than that of clinical ones. We should highlight at this point that the number and turnover of beds is not similar between specialties and an analysis based on absolute numbers and/or rates of PC requested to the hospital it would be biased. Therefore, we have assessed referral rates per specialties, considering the number of hospitalizations in the period, verifying that referrals from clinical specialties $(3.8 \%)$ were higher than surgical ones $(0.61 \%)$. These numbers are compatible with the literature which shows that clinicians request more $\mathrm{PC}$ than surgeons..$^{5-9,23-25}$

\section{Reasons for requesting Psychiatric Consultations}

Among alleged reasons for PC requisition, it was noteworthy that they were only related to problems experienced by patients (whether or not clinical), without mentioning the difficulties that could arise from the patient-physician relationship. Behavioral alterations and diagnostic and/or therapeutical doubts were present in more than half of the requisitions (59.6\%) and certainly the influences from the patient- clinician, patient/ nurse relationships and the relationship of these people with the institution were concealed behind the report of clinical manifestations. In cases in which there was any report of difficulty in this management of the patient, the requisition mentioned exclusively the patient - 'poorly compliant patient' - or doubted if the reason of this attitude (poor compliance) would be restricted to the patient's condition. Again, the relationships were forgotten or denied, as described by Ferrari et al, ${ }^{26}$ in 1977.

The preceding analysis was performed based on data collected and classified from PC requisitions. However, when evaluating the reasons of PC directly from the solicitant, the difficulties identified in the relationship arose and had great importance, as was shown by Ramos-Cerqueira et al, ${ }^{9}$ Ferrari et $\mathrm{al}^{26}$ and Botega. ${ }^{27}$

In $36.2 \%$ of the cases of this sample we identified as the main reason of $\mathrm{PC}$ requisitions a behavioral alteration that somehow interfered with the treatment and/or the ward routine. These alterations were both composed by depressive manifestations (symptoms) and restlessness, agitation and hostility. We may consider that the former, when present and depending on their severity, interfered with the treatment and/or its result, whereas restlessness/agitation pictures interfered with the ward's routine and probably would give rise to feelings of insecurity and fear originated from the unpredictability of the patient's reactions. As patients' management is more difficult and/or their behavior implies risks for them and for the others, the likelihood of referral to PC increases. ${ }^{28}$

Bustamante \& Ford, ${ }^{5}$ assessing the characteristics of referrals to psychiatric consultations, noticed that $35.1 \%$ of them asked for the establishment of a diagnosis; $21.9 \%$ solicited treatment for an observed alteration; $18.5 \%$ needed an assessment of suicide risk; $18.5 \%$ asked for help to manage a problem and $3.3 \%$ reported difficulties in the patient-physician relationship.

Botega et al, ${ }^{7}$ assessing 507 PC of the Clinical Hospital of the University of Campinas (HC-UNICAMP), verified that, in most cases the psychiatrist was called to assess the patient's mental condition, to help in the differential diagnosis between organic and psychiatric pathologies or to accompany patients submitted to traumatic procedures and in $15 \%$ of the cases the 
requisitions were originated from disadjustments in the patientphysician relationship.

In other study, the same author, ${ }^{29}$ now assessing the attitude of physicians with regards to the referral to Liason Psychiatry, found that they always mentioned referring patients with suicide attempt, with acute psychotic disorders and with drug addiction. They said they referred or only rarely used to refer depressive, alcoholic, terminal, mentally handicapped patients as well as those with functional or anxious disorders, polycomplaining subjects or who did not comply.

Mayou \& Hawton, ${ }^{30}$ pointed out that the absence of a clinical diagnosis, as well as a previous history of psychiatric disorder, frequently motivates requisitions to PC. For Cummins et al, ${ }^{31}$ the referrals also would be influenced by each physician's individual threshold.

When analyzing PC requisition forms and the description of symptoms of the patient, it was noticed that in some cases there was at least a 'syndromic' understanding of what the patient actually had. Actually, what was requested was the confirmation or denial of the initial suspicion as well as the help with treatment. In $13 \%$ of the cases there was a generalization expressed by the simplification: - "I request assessment and con$d u c t$ " - leaving unclear for which symptoms, pathology and/or situations experienced by the patient, the team and institution the consultation was requested.

Besides the reasons expressed in the $\mathrm{PC}$ requisition, the presence of a psychiatric diagnostic hypothesis made by the solicitant and its concordance with that of the consultant psychiatrist was also analyzed. Of note, only $25 \%$ of the requisitions had a diagnostic hypothesis and conditions such as alcoholism and depression, considered as frequent in hospitalized patients, had not been more frequently identified. This fact is more relevant in a university institution in which the majority of requesting people are still being formed. Kerr-Corrêa et a ${ }^{8}$ highlighted the importance of $\mathrm{PC}$ as an instrument of educational assessment, as from the analysis of $\mathrm{PC}$ requisitions in two distinct moments it was possible to promote changes in the curriculum of medical schools, emphasizing the most prevalent psychiatric conditions and, after a certain period of time, to check if there has been any improvement in the identification of these pictures by students and medical residents of other specialties.

Cerqueira \& Smaira $^{9}$ highlighted the fact that, as a rule, PC requisitions, besides having non-specific symptomatic data (behavior disorder, anxiety, restlessness, depression, etc.), hid the real reasons of the difficulty to deal with that specific symptom, or rather, with that patient and his/her reaction to the disease.

\section{Psychiatric diagnoses}

As already described in results, psychiatric diagnoses of patients seen by PC were, in order of frequency: mood organic disorder, behavior disorder caused by the use of alcohol and drugs; depressive disorder, anxiety disorder and conversive disorder. In two cases the consultant psychiatrist had not identified a psychiatric pathology. These data differed from those found in the literature, in which several authors have found depressive conditions as the most frequent ones. In two studies with consultation patients, Lipowski ${ }^{32}$ found the diagnosis of depression in $42.7 \%$ and $50.2 \%$, respectively, while organic brain syndromes occurred in $13.9 \%$ and $15.5 \%$ of these populations. Dunningham et al ${ }^{33}$ reported affective disorders $(52.4 \%)$, disorders caused by the use of psychoactive substances (16.6\%), adjustment disorders (14.3\%), neurotic disorders $(11.9 \%)$ and organic disorders associated to somatic diseases in $4.8 \%$ of the cases. According to Bustamante \& Ford, ${ }^{5}$ depression was the most frequent diagnosis $(32.5 \%)$, followed by organic syndromes (17.8\%), adjustment and anxiety reactions (17.2\%) and alcoholism (3.3\%).

Florenzano ${ }^{34}$ studying requisitions of $\mathrm{PC}$ in a Chilean general hospital found more neuroses and reactions $(32.3 \%)$, and organic pictures $(22.6 \%)$, whereas alcoholism had been diagnosed in only $6.0 \%$ of studied patients. Similar data were reported by Millan et $\mathrm{al}^{24}$ in a study performed in the HC-FMUSP. These two studies showed data related to the presence of personality disorders, being $26.3 \%$ in the former and $6.3 \%$ in the latter, diagnosis that was not formulated (what is different of not found) in our sample.

Magdaleno Júnior \& Botega ${ }^{25}$ found in the HC-UNICAMP diagnoses such as: adjustment reaction (24.6\%); depression $(23 \%)$ and organic psychotic conditions (18.8\%).

Of note, a comparison between psychiatric diagnoses presented in scientific studies depend heavily on the criteria used by the authors and on the possibility of comparison. Diagnostic classifications, both those developed for research and clinical ones, have undergone and are undergoing reviews in the last years. Carvalho et al ${ }^{35}$ highlight that this difficulty is due, in part, to a lack of standardization of the assessment and of the diagnostic systems used in PC services.

Still another important fact is that patients seen by PC had, primarily, physical diseases which somehow and at a certain degree could promote changes in the patients' way of being and living in the world, and could also facilitate fantasies regarding their experiencing of the disease/hospitalization/ treatment/results. They are, therefore, patients who could not be considered as having an unchanged psychism. It is also known that many symptoms can have both psychical and organic origins and many times when they co-occur their limits are not precise.

Analyzing diagnoses by gender, we noticed significant statistical differences. The diagnosis of alcoholism was exclusive of men among the cases, and in one woman in the control group. Among women the most frequent diagnosis was depressive-anxious disorder. These data are compatible to those found in the literature and are not necessarily the most frequent ones. But, when present, they have this distribution regarding gender.

\section{Scales}

Analyzing the results obtained with the proposed instruments for this study, of note, the SRQ, a screening instrument, identified in the total sample $41.1 \%$ (29.8 with SRQ $>6$ ) of subjects as probable 'cases', that is, patients who would benefit from a psychiatric assessment/management. From these patients, $35.71 \%$ pertained to the control group and therefore although had a possible psychical suffering were not identified as such. 
It should be highlighted that the used instrument has questions related to somatic symptoms that can be present both in clinical and psychical pathologies. As already mentioned, $30 \%$ to $60 \%$ of patients hospitalized in general hospitals have psychiatric disorders ${ }^{3,35}$ which have several links with the clinical pathology that justified the hospitalization.

The BPRS, used in this study to systematically describe the psychopathology of patients, has shown that both patients identified as needing a psychiatric evaluation and the control group had a symptomatology with anxiety, tension and some degree of depressed mood. These data could be interpreted as an expected reaction to a condition of being ill/hospitalized to which the subject is being submitted. However, the fact that we consider the alterations as reactive ones does not make them less pathological or as causes of suffering and/or a contribution for a worse response to the pathology proper and its treatment.

The patients of the case group had a greater number of psychopathological alterations which were also more severe when compared to the control group. Probably due to that we may suppose that these patients were identified as 'possible cases' by clinicians and surgeons. A certain degree of anxiety, tension and depressed mood, the most found alterations in the control group, are expected and if they do not remarkably interfere with the patients' treatment and evolution they tend to not be recognized as pathological and in this way to be better investigated and treated.

Botega \& Dalgalarrondo ${ }^{29}$ point out that, within the same pathology, the degree of manifestation of the symptoms would be a very important factor in the referral, especially if these symptoms do interfere with the ward's routine.

\section{Conclusions}

We verified that the behavioral alterations both in manifested elation (agitation/restlessness) as well as depression provoked more often requisition to PC. We may suppose that both, somehow, would lead to scarcely collaborative attitudes of patients regarding their treatment and/or would interfere with the ward's routine. In cases of agitation we may also suppose that the difficulty of management is probably due to feelings of insecurity and fear generated in the team stemming from the unpredictability of the patients' reactions.

From the assessed patients, $95.8 \%$ of the cases and $27.7 \%$ of the controls received a psychiatric diagnosis. Organic disorders and those secondary to the use of psychoactive substances were the most frequent among cases, whereas among controls prevailed the diagnoses of depressive-anxious conditions and the abuse of psychoactive substances. Organic conditions were the most identified by clinicians and surgeons as they were more frequent in general hospitals or due to the intensity of their symptomatology or even due to the emphasis that the Psychiatry course gives to this topic for undergraduate students. Reactions to the condition of physical illness, such as those linked to patient-team relationship were scarcely identified.

The use of screening instruments, such as the SRQ and the CAGE - which discriminated between subjects who were patients in 5.43 more times - can be useful in the clinical practice.

Further researches should be performed to assess how the implanted PC service has improved the diagnostic capabilities and the treatment of psychiatric disorders in this university general hospital.

\section{References}

1. Lipowski ZJ. Current trends in consultation-liaison psychiatry. Can J Psychiatry 1983;28:329-38.

2. Steinberg H, Toren M, Saravay SM. An analysis of physician resistance to psychiatric consultation. Arch Gen Psychiatry 1980;37:1007-12.

3. Seltzer A. Prevalence, detection and referral of psychiatric morbidity in general medical patients. J Roy Soc Med 1989;82:410-2.

4. Seward LM, Smith GC, Stuart GW. Concordance with recommendation in a consultation-liaison psychiatry service. Aust N Z J Psychiatry 1991;25:243-54.

5. Bustamante JP, Ford CV. Characteristics of general hospital patients referred for Psychiatric Consultation. J Clin Psychiatry 1981;42:338-4.

6. Kerr-Corrêa F, Silva BCM. Avaliação do ensino de psiquiatria pela análise dos pedidos de interconsultas. J Bras Psiq 1985;34:247-52.

7. Botega NJ, Fontanella BJ, Gonçalves EB, Rodrigues RT. Ambulatório de psiquiatria em hospital geral- alguns dados do HC-Unicamp. Rev ABPAPAL 1988;10:57-62.

8. Kerr-Corrêa F, Smaira SI, Torres AR, Rossini R. É possível melhorar o diagnóstico de alcoolismo? Avaliação do ensino de psiquiatria através de interconsultas em enfermarias de um hospital universitário. Rev. ABPAPAL 1989;11;81-5.

9. Cerqueira ATAR, Smaira SIFJ. Análise comparativa das interconsultas psicológicas e psiquiátricas num hospital escola: reflexos da formação médica. Departamento de Neurologia e Psiquiatria da FMB-UNESP; 1992. [printed text].

10. Almeida OP. O papel do psiquiatra no hospital geral. J Bras Psiq 1990;39:183-9.

11. Harding TW, Arango MV, Baltazar J et al. Mental disorders in primary health care: a study of their frequency and diagnosis in four developing countries. Psychol Med 1980;10:231-41.

12. Mari J, Willians PA. A validity study of a psychiatric screening questionnaire (SRQ-20) in primary care in city of S. Paulo. Br J Psychiatry 1986;148:23-6.

13. Ewing JA, Rouse BA. Identifying the hidden alcoholic. International Congress of Alcoholism and Drug Dependence, 29, Sydney; 1970.

14. Masur J, Monteiro MG. Validation of the "CAGE" alcoholism screening test in a Brazilian psychiatric inpatient hospital setting. Bras J Med Biol Res 1983;16:215-8.

15. Beck P, Kastrup M, Rafaelsen OJ. Mini-compendium of rating scale for states of anxiety, depression, mania, and schizophrenia with corresponding DSM-III syndromes. Acta Psychiatr Scand 1986;Suppl 326:7-37.

16. Zuardi AW, Loureiro SR, Rodrigues CRC, Corrêa AJ, Glock SS. Estudo da estrutura fatorial, fidedignidade e validade da tradução e adaptação para o português da escala de avaliação psiquiátrica breve (BPRS) modificada. Rev ABP-APAL 1994;16:63-8.

17. Organização Mundial da Saúde. Classificação de transtornos mentais e de comportamento da CID-10. In: Dorgival Caetano, tradutor. Porto Alegre: Artes Médicas; 1993. 
18. Malbergier A. Interconsulta psiquiátrica: a experiência do serviço de interconsulta do hospital das clínicas da faculdade de medicina da universidade de São Paulo. In: Miguel Filho EC et al. Interconsulta psiquiátrica no Brasil. São Paulo: Astúrias; 1990. p. 105-8.

19. Shevitz SA, Silberfarb PM, Lipowski ZJ. Psychiatric consultation in general hospital: a report of 1000 referrals. Dis Nerv Syst 1976;37:295-300.

20. Cordioli AV, Dofman M, Sibemberg N, Almeida RA. A consultoria psiquiátrica no hospital de clínicas de Porto Alegre: características dos pacientes encaminhados. Rev HCPA 1986;6:65-8.

21. Smith GC, Clarcke DM, Herrman HE. Establishing a consultation-liaison psychiatry clinical database in a Australian general hospital. Gen Hosp Psychiatry 1993; 15:243-54.

22. Creed F, Guthrie E, Black D. Psychiatric referrals within the general hospital: comparison with referrals to general practitioners. Br J Psychiatry 1993;162:204-11.

23. Millan LR, Miguel Filho EC, Lima MGA, Fráguas Júnior R, Gimenes R. Psiquiatria no hospital geral: experiência de um ano. Rev Psiq Clin 1986;13:33-8.

24. Smaira SI. O serviço de interconsulta psiquiátrica da faculdade de medicina de Botucatu (UNESP): uma análise. In: Miguel Filho EC et al. Interconsulta psiquiátrica no Brasil. São Paulo: Astúrias; 1990. p. 164-73.

25. Magdaleno Júnior R, Botega NJ. IPC no hospital geral universitário. J Bras Psiq 1991;40:95-8.

26. Ferrari H, Luchina N, Luchina IL. La interconsulta médico-psicológica en el marco hospitalario. Buenos Aires: Ediciones Nueva Visión; 1977.

27. Botega NJ. No hospital geral: lidando com o psíquico, encaminhando ao psiquiatra [Tese de doutorado]. Campinas (SP): Universidade Estadual de Campinas; 1989.

28. Fauman MA. Psychiatric components of medical and surgical practice II: referral and treatment of psychiatric disorders. Am J Psychiatry 1983;140:760-3.
29. Botega NJ, Dalgalarrondo P. Saúde mental no hospital geral. São Paulo: Editora Hucitec; 1993.

30. Mayou R, Hawton. Psychiatric disorder in the general hospital. Br J Psychiatry 1986;149:172-90.

31. Cummins RO, Jarman B, White PM. Do general practitioners have different referral thresholds? BMJ 1981;282:1037-9.

32. Lipowski ZJ. Review of consultation psychiatry and psychosomatic medicine 1: general principles. Am J Psychiatry 1977;134:233-44.

33. Dunninghan W, Aguiar WM, Farias Junior N. Estudo epidemiológico das interconsultas psiquiátricas em hospital geral: considerações nosográficas e terapêuticas. Bol CBPTD Supl Arq Bras Med 1993;67:455-8.

34. Florenzano R. Interconsultas psiquiátricas en hospital geral. Rev Med Chile 1981;109:661-7

35. Carvalho TR, Lima MG, Pondé MP, Caetano D. Diagnóstico em interconsulta psiquiátrica: experiência de uma pesquisa realizada no HC-Unicamp. J Bras Psiq 1993;42:157-60.

\section{Correspondence:}

Sumaia Inaty Smaira

Departamento de Neurologia e Psiquiatria

Faculdade de Medicina de Botucatu - UNESP

Rua Rubião Jr, s/n

Caixa Postal 540

18618-970 Botucatu, SP, Brazil 